Pastoral care of mental illness and the accommodation of African Christian beliefs and practices by UK clergy

Gerard Leavey

Ulster University

Kate Loewenthal

Royal Holloway, University of London

\title{
Michael King
}

Charles Bell House, University College London

\section{Corresponding Author:}

Professor Gerard Leavey

Bamford Centre for Mental Health \& wellbeing

Ulster University

g.leavey@ulster.ac.uk 


\begin{abstract}
Faith-based organisations, especially those related to specific ethnic or migrant groups, are increasingly viewed by secular western government agencies as potential collaborators in community health and welfare programmes. Although, clergy are often called upon to provide mental health pastoral care, their response to such problems remains relatively unexamined. This paper examines how clergy working in multi-ethnic settings do not always have the answers that people want, or perhaps need, to problems of misfortune and suffering. In the UK these barriers can be attributed, generally, to a lack of training on mental health problems and minimal collaboration with health services. The current paper attempts to highlight the dilemmas of the established churches' involvement in mental health care in the context of diversity. We explore the inability of established churches to accommodate African and other spiritual beliefs and practices related to the etiology and treatment of mental health problems.
\end{abstract}

Key words: faith-based organisations, pluralism, ethnicity, secularism, mental illness, religion 


\section{Introduction}

The present study has its origins in a programme of research on ethnicity and mental illness in which we were struck by the level of contact with faith groups and clergy (Cole, Leavey, King, Sabine, \& Hoar, 1995). However, we had little understanding of what clergy actually did. How did they conceptualise mental illness? What sort of pastoral care or advice did they provide? Did they view themselves as rivals to, or partners with, mental health services? Such issues may be significant in the recognition and management of emotional and psychiatric problems in the faith communities. In previous work, we discussed how clergy from different faith groups conceptualise and manage mental illness, and the implications of this for collaboration with psychiatric services. Pastoral care provision relating to mental health is likely to be influenced by ontological-theological beliefs about role of the supernatural in human affairs, ethnic background and community needs (Leavey, 2004; Leavey, 2010). For example, Western-born clergy, exposed to secular biomedical concepts of disorder and influenced by professional exchange in non-religious contexts, may be more sensitive to accusations of colluding with superstition than those not so exposed. Thus, the management of mental illness may be more likely to be placed in the hands of professional psychiatric services (Leavey, 2010). Barriers to effective pastoral mental health care such as minimal training and inter-professional collaboration, low confidence and clergy stress have been covered elsewhere (Leavey, Loewenthal, \& King, 2007; Leavey, Rondon, \& McBride, 2011). Despite the potential benefits to a partnership between psychiatry and faith based organisations, UK psychiatry tends to resist collaboration with faith based organisations (Dura-Vila, Hagger, Dein, \& Leavey, 2011). Overall, the development and implementation of collaborative 
relationships between the health and religious sectors, in the UK certainly, remains unexplored (Leavey \& King, 2007).

A major and largely unanticipated theme arising from the study was the issue of providing pastoral care in a multi-cultural setting. Thus, the social context and political context of this study is relevant. Many of the interviews took place within Haringey, a borough of north London where Victoria Climbié, a young black girl from Cote d'Ivoire, was murdered by her aunt and her aunt's partner. The inquiry (Laming, 2003) that followed this tragedy highlighted both the dangers of specific religious beliefs (demonic possession) and the complex tensions and dangers of managing multiculturalism in health and social care services (Laming, 2003). In brief, the child had been in the care of her aunt who, whether out of unaccountable malice or mental illness, maltreated Victoria to the point of death. Evidence provided to the inquiry team revealed that her aunt had believed the child was a witch and several African Pentecostal churches appear to have colluded with this belief. The responsible health and welfare services, paralysed by a combination of low staffing and professional and cultural incompetence failed to intervene.

The hypervigilance among some African communities, both in Africa and the African diasporas, with regard to the presence of so-called "child witches" and the often fatal consequences for such children has provoked alarm among health, welfare and criminal justice systems (Cimpric, 2010). While the criminal justice system is relatively restricted in its accommodation of culturally determined behaviour, the softer caring institutions in Western countries have increasingly assumed a regard for cultural competency in theory and practice (Sue, Arredondo, \& McDavis, 1992). The mental health system in the UK, over the years challenged by charges of racism and discrimination, has striven to deal with racism and to develop cultural competencies 
across its staff. However, as the Climbié case revealed, medical and welfare agencies remain troubled by these issues. At the time of the inquest into Victoria's death, relatively little was made of the religious aspects of the case; religious institutions were not on trial and it was perhaps unhelpful to divert attention from the failure of statutory services. However, the actions of the Pentecostal ministers highlight the connection between beliefs and actions, the importance of theodicy and helpseeking behaviour.

Religion and help-seeking are connected by symptom recognition and cultural beliefs on the aetiology of illness and misfortune. For example, many people perceive their problems to be spiritual rather than mental; others look to religion as a means of understanding suffering and also, a strongly beneficial way of coping with it (Maton, 1989; Pargament, 1997; Zuckerman, Kasl, \& Osfield, 1984). Sometimes, the articulation of spiritual or religious views can point to the existence of genuine pathology, but among people in charismatic groups, for example, profound religious experience, usually ecstatic, may be considered desirable and beneficial (Csordas, 2002; Glik, 1988; Jackson, 1991; James, 1902). Religious beliefs whether or not allied to broader cultural conceptualisations of illness and misfortune are likely to have some bearing on the recognition of mental illness and its management across different religious groups within an increasingly secular society and already secularised health institutions. Thus, the identification of psychiatric problems by patients, family and community members as supernatural in origin may lead to delays in reaching professional psychiatric help ot complicate the patient's relationship with mental health workers. The relationship of clergy to secularist about suffering and misfortune is likely to be important. Thus, do clergy understand and explain such 
phenomena in supernatural terms or have they assimilated biomedical or psychiatric explanations? Are they able to accommodate both explanatory models?

In tandem with secularisation, globalisation has profoundly altered the patterning of religious beliefs and behaviour in Western countries such as Britain. While a large proportion of the white British-born population have disappeared from the pews their places appear to have been taken by people from Africa and the Caribbean. More generally, the growth sectors of faith communities are found among Muslims and Pentecostals. In parallel, the attrition and diminishing recruitment of home-grown priests means that the Roman Catholic Church increasingly relies on Africans and others to run parishes. Such changes are likely to disturb comfortable and commonly shared theological and ontological certainties held by clergy and their parishioners. Although the British policy of multiculturalism has dominated race relations for over 40 years, it is considered by some as failing to deal with racism or build community cohesion (Parekh, 2000). Usually however, the examination of multiculturalism and its difficulties tends to focus on the provision of goods and services in the statutory sectors (health, welfare, education). Of interest is how the established churches, by which we mean a group of mainstream, institutionalised churches such as the Anglican Communion, Roman Catholic or Methodist churches, with a historical base in Britain dating back more than a century, have responded to the arrival of new communities and foreign-born clergy. In the past, established churches have reacted with a degree of hostility, suspicion and ultimately accommodation. For example, we might consider the experience of Irish Catholics arriving in England post-famine in the second half of the $19^{\text {th }}$ century, whose problems were provoked as much by their theology as by their ethnicity (Swift, 2002). 


\section{A Spiritual Marketplace}

Finke and Stark's (1992) study of supply side religious economic theory ${ }^{\mathrm{i}}$ suggests that even though establishment churches decline, supernatural beliefs and spiritual experientialism remain constant and evangelical movements, fringe faiths and cults have grown to meet the demand. Thus, they conclude that the theory of secularism is overstated. Other commentators point to the vibrant expansion of black, predominantly African and Pentecostal communities in the UK whose beliefs and practices, as this paper explores, seem to provoke a degree of anxiety among clergy from the established churches and perhaps more widely in public discourse, a degree of 'moral panic' in relation to aspects of multiculturalism. In sociological terms, 'moral panic' refers to an institutional response to people or phenomena that is disproportionate to the actual threat (Cohen, 1973).

These anxieties resonate, ironically perhaps, with the attitudes and behaviour of the white Christian churches in the 1950's post-Windrush period of Caribbean migration to Britain when black migrants, alienated by the frosty reception of the established congregations, set up their own churches (Calley, 1965; Gerloff, 1992). However, as Toulis (1997) points out the new black churches were not simply a response to racism; African-Caribbeans were equipped with a strong religious identity shaped by an African cultural inheritance and their experiences within slave and colonial society. Thus, adversity was not new, neither was their experience of white English culture. Moreover, Revivalism, a significant element of Caribbean religious history, emanated from the syncretism of African religion and Christianity and was characterised by dramatic and emotional displays of belief and worship such as dancing, falling prostrate, prophesying, trance and spirit possession. To the 
mainstream missionaries this emotionalism was all too alarming and they attempted, unsuccessfully, to eradicate Revivalism, which then became a core feature of Jamaican African Christian cults (Curtain, 1955). Arriving amidst decline in the mainstream churches, Pentecostalism is emerging as major force in developing and developed countries alike, including the UK (Martin, 2002). D'Epinay provides a functionalist explanation of Pentecostal expansion as an attempt by the displaced poor to counteract the anomic forces of modernism and urbanisation (D'Epinay, 1969; Durkheim, 2001). Thus we now find Pentecostalism well-embedded in the large African diaspora in the UK (Hunt, 2001).

\section{Clergy and help-seeking}

If clergy act as brokers for mental health help-seeking behaviour in communities where a variety of cultural beliefs share an uncomfortable space, it is important to examine their ability to manage any conflict between psychiatric support and such beliefs. Although, there is an assumption on the part of some commentators as to the shared cultural knowledge and beliefs between clergy and the help-seeker (Friedli, 1999), within very transient and diverse communities this may not be the case (Leavey, 2008). Moreover, the death rattle of the traditional 'white' Christian churches has been increasing for some time (Bruce, 2002); their survival may depend on their ability to meet the spiritual and other pastoral needs of people from diverse ethnic and cultural backgrounds. However, church revisioning towards relevance and sensitivity to minority ethnic communities may demand something more than understanding the relatively anodyne aspects of cultural competence such as knowledge about structures and communication of family authority. What if the cultural accommodation required profound adjustment to matters of church belief and ritual? 


\section{Objectives}

This study aimed to examine the problems of mental health pastoral care faced by clergy working in inner-city multi-ethnic communities. In particular, we explored the problem of cultural competence among clergy serving ethnically diverse communities. Although Christian, Jewish and Muslim clergy participated, the findings presented here are restricted to how clergy in the established churches (predominantly Anglican and Roman Catholic) navigate the dissonant Christian beliefs of their black [(predominantly African or of African heritage)?] congregation members. We examined how these beliefs and spiritual needs, are accommodated in the context of a religious marketplace and the increasing presence of charismatic and African Pentecostal churches.

\section{Method}

This is a qualitative study in which we used a purposive sampling or theoretical strategy commonly associated with grounded theory whereby the compilation and analysis of the data are consciously linked (Strauss \& Corbin, 1990: 67). Thus, the data gathered from the initial interviews were employed to inform further data collection requirements and thus, ultimately, the selection of informants. This assisted in the exploration of the parameters of the study and provided opportunities for increasing the 'density' and 'saturation' of significant, recurring or ambiguous categories. Thus, the data collection and analysis were treated as interdependent or dialectical activities, which provide an indication of the new informant/s required to give credence to, or invalidate, an evolving hypothesis. For example, non-spiritual explanations of mental illness seemed to predominate in the interviews with white 
mainstream Christian ministers while conversely spiritual explanations were significant among black Pentecostals. We therefore sought additional and different voices from these respective faith groups in order to distinguish between ethnic and theological influences.

\section{Sample}

In the main study (Leavey, 2008), we undertook 32 interviews with clergy from a range of religious and ethnic backgrounds (European, African, African-Caribbean and South Asian). However, the current paper is based on clergy, all males, from Christian faith groups only. They are five Roman Catholic (one White Irish, four White English), five Church of England (one Black Nigerian, four White English), seven Pentecostal (two African-Caribbean, four Black African, one White English) and two Baptist (one White English, one African-Caribbean).

\section{Interview}

The interviews were conducted face-to-face by GL using a topic guide developed for the study and which was based on key issues that were identified from the literature on religion and mental health. These were based on Kleinman's explanatory models questions on mental illness (Kleinman, Eisenberg, \& Good, 1978), discernment and pastoral care and collaboration with mental health services. The interview began with questions related to the clergy's background, their career and training in mental health problems. It then moved to an exploration of the clergy's experiences of mental illness within their congregation and community, how they interpreted and managed such problems, and finally, what they needed to assist them in mental health pastoral care. We defined and discussed 'supernatural' causes and events as phenomena that 
are beyond what is natural or can be explained by science. At various intervals and after each complex response a synopsis of the discussion was related back to the interviewee to allow for clarity and/or confirmation. We also attempted to clarify whether beliefs were the personal or idiosyncratic views held by individual religious leaders or whether they were generally held by the wider religious organisation and community. The interviews, with two exceptions, were all recorded in accommodation attached to each ministers' place of worship. The purpose of the study was explained to each participant before the interview ${ }^{\text {ii }}$. Each interview lasted between 60 and 180 minutes with an average duration of 90 minutes.

\section{Setting}

The majority of Christian clergy worked in areas of considerable deprivation (e.g. high levels of unemployment) and ethnic diversity ${ }^{\mathrm{iii}}$. In contrast to the other religious denominations these mainstream Christian leaders emphasised the ethnic diversity and high mobility of their congregations. For example a Church of England minister working in north London reported that his local non-church primary school has an annual mobility of $30 \%$ and that this is also seen in the church going population. In his school there were 74 different community groups and ethnicities; $75 \%$ of the children have English as a second language. Many of the smaller Pentecostal churches tend to be ethnically homogenous, predominantly serving West African communities or African-Caribbean communities. The larger, more affluent and corporately organised of the Pentecostal groups appear to attract greater diversity among the black communities (Hunt, 2001).

\section{Ethical Approval}


This study was granted ethical approval by the Research Ethics Committee of University College London.

\section{Findings}

The findings are covered within the following thematic headings: (1) African Christianity; (2) Cultural sensitivity; (3) Division; and (4) Threats from the Pentecostal and 'breakaway' churches. With regard to help-seeking and the provision of mental health pastoral care there are perceived limits on clergy influence in their faith communities. Primarily, clergy described a dissonance between clergy explanations of emotional and psychiatric distress and those of the laity. While clergy may not wholly abandon supernatural explanations of mental illness, they tend to downplay such phenomena, unlike some members in their faith community (Leavey, 2008; Leavey, et al., 2007). Second, white mainstream Christian clergy appear to lack the confidence and knowledge to provide multi-cultural care. Clergy may be unable and/or unwilling to offer the assessment and treatment that the laity from African Christian backgrounds need or want. In the background to these pastoral troubles is the decline in the established churches, compounded by the growth of African communities, and anxieties related to the phenomenal expansion of black Pentecostal churches in UK cities. The identities of the individual participants have been anonymised.

\section{African Christians}

The themes of culture and cultural sensitivity were not anticipated and arose wholly unprompted by the researcher. Significantly, the problems of understanding mental illness and delivering pastoral care in a multi-ethnic setting was a major theme among 
the white Catholic and Anglican clergy. Among black and ethnic minority clergy from the same churches these and related themes did not arise or at least provoked minimal concern. A Nigerian-born priest jokingly declared that he came to England to do missionary work "to restore Christianity to the English". The concern among nonEnglish clergy, mostly attached to the evangelical movement, was that the English have dangerously removed a fear of the supernatural from their world and have lost, consequently, a sense of God.

A white Baptist minister who was drawn to charismatic beliefs and behaviour in the 1960s, finding it "liberating" and "biblically authentic," has since come to distance himself from this religious stream. While still holding an evangelical, though "not fundamentalist" perspective, he is concerned about "certain foreign imports".

More recently some of the American brands have worried me and some of the African brands too, I find - it feels much less authentic.

The white clergy suggest that although they are 'preaching the one gospel' to everyone in the congregation - non-indigenous Christians receive the message somewhat differently. For example, the white clergy from the established churches wholly reject the possibility that God will punish the wrongdoer with illness but, as one Anglican suggested, such beliefs are retained within the congregation. Thus there exist conflicting theological beliefs on the valuation of sin, divine retribution, belief versus superstition and the implication of the supernatural in personal misfortune.

I have come across, good Christian believers who would say - some in my own congregation and particularly among the African and West Indian members - who will say quite openly that they think that God punishes wrong doers with illness and sometimes with madness. 
In one Catholic parish, English families are a distinct minority. The nearest white European group are the Irish who make up about $10 \%$ of the congregation. Sixty percent or more of the congregation are Africans, predominantly from Nigeria or Ghana. As illustrated by the following quote from a white Catholic priest, cultural difference creates difficulties in discerning mental illness among his congregation.

With Africans, there is more of a blurred area of what constitutes a mental health problem.

He provided an example of a Nigerian woman in her sixties who visited the priest on a number of occasions and who told him that the "fire brigade are causing the birds to attack her in the street". To him, the woman clearly had considerable mental health problems but she was deeply convinced that only the priest could intercede through prayers, crucifixes and holy water and "people to bless the house - all those other religious paraphernalia, rigmarole stuff'. He had tried for some time to explain to her that he could not "solve it for her and that whatever the cause is, it's not religious or spiritual or evil spirits". Her daughter expressed concern but because this woman's behaviour was manageable, they didn't feel 'compelled to seek professional help'. With some discomfort, the priest wondered if he should be urging the woman's family to seek mental health services on her behalf.

His narrative of these events signifies a number of important issues. Firstly, it reveals a degree of rejection, as non-rational, of catholic religious "paraphernalia" and ritual as intervention for personal suffering. Secondly, the priest suggested that such beliefs remain "amongst the African members of the congregation, and to a certain degree among Caribbean peoples". However, his presentation of the woman's illness suggests no particular cultural origin, per se, but her confidence in a spiritual 
intervention substantiates an African tendency to account for misfortune though supernatural forces. He suggested, "the thing (belief) is most acute

...It's just a belief that black magic - I'm sure there are other better words than that for describing this scenario.... but you can interfere with the normal running of the world by appeals both to good forces and to evil forces and that's a very, very deeply ingrained belief in a lot of the people that come to church.

Another white Catholic minister described his encounter with a young African couple whose first child died and the second baby was sick. Convinced that somebody in Nigeria had "cast a spell on them so that they will never have a happy family life together" they asked the priest if he would say whatever prayers are necessary to remove the curse. They offered to pay the priest whatever money was needed for this in order to be able to counteract this spell.

Now in order to deal with a situation like that, I try and get them to reflect to me who they think God is and how God interacts with the world and why God would allow somebody who was evil to be able to have power over somebody who is good, arguments of that sort.

To him, the proposed transaction was quite disturbing despite the fact that he himself has spent a couple of years in Nigeria and appeared both knowledgeable and accepting about cultural beliefs and customs as practiced there. His negative reaction appeared to be aroused by the anomalous displacement of such beliefs in a nontraditional western setting (cf Mary Douglas on taboo and matter out of place: 2002). He attempted to remove from them (African and in the priest's view, pre-Christian) beliefs that 
...they don't wish to acknowledge but which somehow makes them feel safer and securer in the world of manipulation than in the world of true Christian freedom as I understand it.

\section{Cultural Sensitivity}

The dilemma for white UK-born Christian clergy is how to balance liberal Christian attitudes, which include notions of multiculturalism and cultural sensitivity, with a modern western theology, which appears opposed (or at the very least, ambiguous) to this type of supernatural belief. The clergy offered limited strategies to manage this dissonance. Thus, unfamiliar beliefs may be confronted as unacceptable or misguided, leading to theological re-education. Alternatively, depending on the circumstances, clergy permit themselves a degree of collusion.

The following quote shows how one priest, a white Anglican, felt compelled to ontologically re-orientate the individual. Bearing in mind the disregard of the historical church-colonial enterprise in Africa, the discourse carries an implied shallow and psychologically enslaving ideology within African Christianity.

Although I am very sensitive to the ambiance in which feelings and emotions of this sort emerge, I certainly don't feel it's my job to reinforce a false image of how the world works and how one interacts with the world. It's my job to try and help the person to come to a deeper and a freer understanding of their role in the world.

However, whatever the desire to challenge parishioners' magical 'manipulative' beliefs, there are exceptionally emotional situations of personal tragedy when these are invoked and which the clergy let pass. 
There was a car accident and a family member was severely injured somebody came this morning asking for a little bottle of holy water because they are going to the hospital and they want to sprinkle the holy water. Of course I respond immediately to the situation and sort of file away at some future stage, when things are not so acute, that we really need to have a discussion about what this use of holy water signifies and means in that particular circumstance.

In this instance the priest appears to have colluded with the family's belief in the potential power of the holy water (intervention) out of respect for their anxiety and desperation for help. The use of holy water somehow goes against his theological beliefs but ultimately such interventions do no harm and may give comfort and hope. The interviewer suggested to him that from within his own experience of Irish Catholicism, this type of intercession and use of holy water is commonplace. The priest responded, somewhat tetchily, that many Africans have too profound a belief in the 'efficacy' of the holy water - and, unlike other groups, Africans will rely solely on the power of the water rather than consulting a doctor for help.

Overall, while clergy were acutely aware of theological differences between black parishioners and the church, there appears to be no centrally organised or locally concerted effort to challenge and eradicate African Christian beliefs. It is more likely that these views are, for the most part, accommodated as unpleasant but relatively harmless - that is, until such beliefs have potentially legal ramifications or the challenged parishioners find their beliefs better articulated externally. 


\section{Division}

A white Anglican priest with similar concerns about cultural beliefs deemed antithetical to modern Christian sensibilities had an ethnically diverse parish containing many African parishioners. Significantly, much of the specific cultural distance that he perceived between himself and the black congregation was attributed by the priest to a heightened belief in the supernatural and divine intervention among Africans. However, these concerns were not only expressed as difficulties in managing the beliefs of individuals but as threats to the pastoral maintenance of whole groups of parishioners, mostly Nigerian.

To illustrate, he described how these groups were involved in the problems experienced by a teenage girl in his congregation who had experienced difficulties at school- difficulties, he suspected, that were created through the incompatibility between the ethos of a modern Western liberal school and kind of regime and 'an old fashioned Nigerian strictness' at home. The conflict between the two cultural systems generated 'wild behaviour'. When the girl starting 'acting out' the parents called a prayer meeting to which the minister was invited and "at which we were all invited to drive out the devil of disobedience from this child". The minister declined, feeling that he had "witnessed an act of abuse" even though "it was done for very, very loving and caring but misguided reasons". He wasn't clear about the beliefs and motivations behind 'the ritual to drive out the devil' as he perceived it, but suggested that cultural beliefs about the nature of evil and the devil eschew personal responsibility. He personally believed in an 'external' or objective reality of the devil; that is, "the devil is not simply a projection of our internal desires". However, while he recognised the possibility of demonic temptation, there has to co-exist a degree of human responsibility. Importantly, his perception of these events as abusive resonates with 
the concerns raised by other white ministers about the Victoria Climbié case in which a young girl from Cote d'Ivoire was violently abused and then killed, and whose aunt had taken her to local Pentecostal pastors for exorcism (Laming, 2003). The clergy in the established churches viewed such highly publicised cases as bringing all religious bodies and clergy into disrepute.

Despite this, through the growth of the African congregation, he argued, Africans had injected a renewed Christian energy which had "undone some of the damage" he perceived to have been wrought by the church over the past twenty years in its attempt to be "relevant to people," including democratisation, demystification and loss of tradition - secularising processes within the church. Nevertheless, while addressing the issue of sin as a possible cause of mental illness he suggested that ...there are strains within Christianity, usually of foreign origin, which preach, or at least imply a powerful message of divine punishment for wrongdoing and a materialist version of salvation which jars with English Anglicanism.

In this he was referring to the 'health and wealth' Christianity currently popular in the African, usually Pentecostal, churches (Hunt, 2001).

We do have many people who are influenced by these ideas who preach and teach here in congregations. You will find there, that the idea that if you do good by God then he will shower blessings on you, and in this way you know - and so if you're a good man then God will bless you. ...And it's a short step from that - to say this person is ill, therefore this person may be a sinner. This person is suffering - therefore there must be something that this person has done to deserve that and I think that that is a very widespread view.

The views of this priest were not only supported by the other white mainstream ministers but were articulated by a black African and an African Caribbean (Anglican 
and Baptist ministers respectively) who acknowledged the presence in their congregations of supernatural beliefs to which the clergy are opposed but which they find hard to eradicate. For example, the Baptist minister described his difficulties dealing with 'outsiders' coming into the church.

Some members have come in from different churches and they would, if you're not strong enough, impose their brand of beliefs and doctrines and when these things happen it causes conflict in the church. So you have to be aware of these things, you know, before trouble starts.

\section{Threats from the Pentecostal and 'breakaway' churches}

The concerns of the white clergy cannot be viewed in isolation from an increasing turbulence in the religious market, not least the rapid growth of the African Pentecostal churches throughout the inner-cities. In every interview with members of the mainstream Christian ministries, concerns were raised about the growth of Pentecostalism in the UK, and the Pentecostal attitudes to Satan, sin and spiritual healing. The white clergy trace the spread of such highly supernatural beliefs through the growth of the charismatic branches of the church allied to American-style evangelism but also, importantly, to a style of worship and belief taken up with relative zeal among the African members of their congregations.

A white Anglican minister described how he had recently attended one of the regular ecumenical meetings in the locality where one of the Pentecostal ministers, for whom he had considerable respect, said to his colleagues that "God will bless our community when we bring it back to God - the real solution to well-being in our community and to affluence is to come back to God". The minister reflected on this as "frightening" because to him it was such a powerful (and in his view, wrong) 
interpretation about the origins of distress in society but the Pentecostal minister had said it so easily "that it was clearly just part of the background". He then swiftly moved to relate how a group of his Nigerian congregation members that "he knew and respected" moved on to set up their own "charismatic" church within the parish.

Some of the white clergy understand that the dissatisfaction of Nigerian and other African congregants with the mainstream churches arises from a desire for worship in their own language, the need for strong leadership and a rejection of the "quiet style of worship" found in the English churches. This view was supported by the Pentecostal clergy who distinguished themselves from the white churches by the charismatic tradition of "more lively ways of worship". One white Anglican priest explained that these issues may be resolved "by hiring a hall putting some leaflets round inviting people to come and join you in worship and calling yourself a pastor". The establishment of new churches was described as a 'do-it-yourself' type of “amateur enthusiasm" facilitated by the lack of any legal or bureaucratic barriers. Thus as the priest suggested, people can become Pastors if they participate in some of the many accredited courses that exist - "you can pay to do them or you can just set yourself up and do it yourself whatever you like". Once established the churches can then gain some credibility by linking themselves to the existing Pentecostal networks or the Evangelical Alliance. ${ }^{\text {iv }}$

A black Baptist minister also expressed concern and sadness for the declining numbers in his church which is explained partly by a perceived growing secularism within the African-Caribbean community but also the threatening competition posed by the growth of powerful, well-financed evangelical churches, mostly Pentecostal, which according to the pastor offer "bargain-basement" style religion with lots of "razzmatazz entertainment". He comments wryly that most of the quiet, traditional 
style churches are unable to compete with the "amusement on offer" in these giant stadiums but he detects a trend whereby other churches "getting on the bandwagon just to attract people."

... You know, visionaries who can come in and excite people, inject new life and carry people along with them, so people like myself - now we are on the way out.

\section{Discussion}

The effective treatment and management of illness, physical or mental, requires an acknolwedgement of the individual's understanding and experience of the illness (Kleinman, 1981). This is true whether it is psychiatric care or pastoral care that is being sought. In previous work we noted the different ways that clergy from different religions and ethnic backgrounds respond to people who seek help for mental health problems (Leavey, 2008; Leavey, et al., 2007). In the current paper, we note that clergy in the established Christian churches may experience discomfort in the management of such problems among minority ethnic parishioners, and in particular, a concern about alternative worldviews within African and African-Caribbean spirituality. In part, these may be simply taken as the anxieties of liberal clergy, participants in an increasing secular culture, feeling discomfiture with the (re)emergence of beliefs considered as deviant to contemporary Western Christianity. These may also be anxieties of the established churches, keen to avoid the potential collateral damage to Christianity emanating from stories of possession, child abuse and exorcism in the African, mainly Pentecostal churches. The fear has less to do with an inability of the media and other commentators to distinguish between white mainstream and African theologies than with the fact that such episodes are crude but 
useful weapons in the secularist armamentarium. Thus, the presence of expressive African spirituality provokes embarrassment among the white liberal clergy. There also appears to be an anxiety within the more established black churches about the growth of the Pentecostal 'super-churches', vast auditoria holding many thousands. However, concerns about the dwindling white congregations must, surely, increase the value of congregation members who aren't white European, and the need for their retention. In this scenario, clergy must tread cautiously between benign understanding of beliefs currently considered as alien, and continued repugnance and attempts at reorientation, the latter, likely to fail, ultimately.

These tensions relating to issues of globalisation and multiculturalism reflect the difficulties experienced by many Western public institutions in managing diversity, authority, customer power and alternative provision. Thus, the National Health Service in the UK has struggled with the appropriate provision to minority ethnic communities for the past four decades, amidst accusations of racism, discrimination and cultural insensitivity, variously (Gerrish, Husband, \& Mackenzie, 1996; Sashidharan, 2001; Singh, 2007). In the discussion that follows we argue that cultural beliefs (particularly those of theodicy and soteriology) generate difficulties of legitimacy for clergy. We outline the problems of the church in dealing with matters of orthodoxy and the emergence of an alternative black African Christianity in Britain.

\section{Cultural Dissonance}

Many white clergy from the established churches in the UK appear to have incorporated rationalist bio-medical beliefs on the origins and process of mental illness which are at times perceived to be at variance with those of congregation 
members from black and ethnic minority backgrounds. However, we might ask why clergy find the beliefs of the African members so difficult to accommodate.

To offer some context, one may point to a long standing dissonance between church and laity. Religious leaders, while a part of society are also considered within some faith communities as special, placed apart from society through what Weber termed charisma, and governed by a separately constructed and overlaid framework of beliefs and rules (Weber, 1947, p.: 359). Thus, implicitly and symbolically clergy are differentiated from the lives and the mundane concerns of the followers. However, the corporate rules within the established organisations are not static and neither are clergy beliefs, as more dramatically demonstrated by schism. Importantly, official beliefs may not always be in tune with those of the congregations. Indeed, it may be argued that clergy and laity have seldom chimed and are increasingly fractured in the $21^{\text {st }}$ century as a result of child abuse scandals, among other things (Terry, 2008).

Several, sometimes contradictory, issues are salient here. Firstly, church members may be reluctant to accept change in liturgy or belief (For instance, see Mary Douglas on the Vatican Council 11 changes to Friday fasting 1996: 39-56). Secondly, organised religions have a long history of pragmatically absorbing and appropriating indigenous, alien or competing religious narratives, beliefs and rituals (Armstrong, 2000; Jasper, 2003: 222).

At other times, clergy and faith organisations battle against the varied and vestigial elements of this accommodation which the churches come to regard as unsustainable or embarrassing. Grace Davie makes a similar point in relation to spiritual eclecticism within Christianity generally, a spectrum of "distinctly heterodox ideas: for example ....healing, the paranormal, fortune telling, fate and destiny, life and death, ghosts, spiritual experiences, prayer and meditation, luck and superstition." 
(Davie, 1994: 93) Lastly, post-modern societies are characterised by departure from the traditional sources of authority ${ }^{\mathrm{v}}$. Thus, it may be argued that individuals have a rather more fluid membership and belief system within their primary religious communities, one that reflects an unwillingness to accept as 'carte blanche', dogmatic belief or moral prescription (Roof, 1999: 36).

However, it is also important to consider the shifting ideological tectonic plates between the evangelical and liberal wings are increasingly, but not entirely, located within an intense politico-cultural strain between the conservative African churches and the 'secularising' western churches in the USA, Australia and Britain. Additionally, the mainstream churches in these countries, as noted in this study, are no longer predominantly enclaves of white British but open to diasporic minority ethnic groups with divergent cultural beliefs and practices. Thus, a post-colonial, rapidly expanding and self-confident African Christianity numbering 300 million by the end of the millennium (Martin, 2002: 132) has managed to redefine itself, in relation to the old European churches, by reabsorbing indigenous African beliefs and practices (described by David Martin as a "bottom-up" inculturation) (2002: 135). Through this Africanisation of the church (Hunt, 2001; Pennacini, 2013) beliefs such as ancestor worship are more easily accommodated than hitherto. Additionally, ritual healing is a central concern and activity (Smart, 2005: 344-60). In a determinedly dualistic cosmology there is a need to promulgate the certain existence of Satan and his presence in human misfortune. Human salvation, both spiritual and material is achieved only through conversion and deliverance. In keeping with a literalist view of the inerrancy of the Bible, spirit possession and the rite of exorcism are restored to their original significance (Cox, 1996). However, beliefs and activities related to 
demonic possession and exorcism seem to draw the church into public condemnation of this activity (Green, 1996: 376).

For the mainstream clergy, there may be more at stake. If we are to concede the existence of a religious and spiritual marketplace with an increasing variety of 'consumers' and 'sellers' of beliefs and rituals, then what the churches identify as their own brand or product may be crucial to sustaining or losing their market share of believers; the tension between what is deemed to be 'respectable' spirituality and 'unacceptable superstition' may be crucial. In a climate of intensified and incensed debate about the inerrancy of the bible, concepts of the devil, sin and possession are seen as indicators of clergy theological position on the evangelical-liberal divide. Thus, the issue of supernatural explanation for illness and divine intervention and healing epitomises the difficulty for most mainstream religious leaders who, in the course of these interviews, often attempted to navigate between rationalist, science based explanations for phenomena that are perceived as supernatural and which occupy a central position and role within religion - phenomena which are, in themselves, displayed as proof by the religious as evidence of divine or other supernatural power.

Visions, voices and demonic possession cannot be dismissed entirely because of biblical precedent. Yet, in the midst of these beliefs, supernatural explanations for distress are seldom considered. For example, mainstream Christian clergy suggest that the concept of the devil is more symbolic than real, a projection of human difficulty in expressing socially unacceptable feelings, thoughts and desires. Thus, the clergy's discussion of the devil and internal desires is often ambiguous and the language of 'voices', 'desires' and 'emotions' are synonymously employed.

Conversely, the Evangelical wing of the Church of England, within which the African 
clergy is well represented, affirms the 'literal truths' of sin and the miraculous and the demonic as described in the Bible. These views are accommodated, albeit reluctantly, within the broader, liberal church. A reading of the Church of England's publication “A Time to Heal” illustrates this compromise very well (Church Review Group, 2000). This lengthy report follows a previous document which was commissioned by the Church of England to provide guidance on the provision of healing services within the church and to encourage understanding between the clergy and the medical profession (Archbishops Commission, 1958).

This document may be seen in the context of religious and spiritual realignment in the UK whereby, as remarked on previously, increasing numbers of people are in search of an eclectic, often esoteric range of healing modalities that have a vague spiritual content. The Church of England's response to this emerging pattern of spiritual behaviour has been to retrace its own healing origins with the intention of re-energising its ministry and competing for the lost souls. In many ways 'A Time To Heal' is an important document not least because it attempts to provide guidance to clergy on how to manage suffering in their congregations but also because it attempts to deal with the problem of discernment between mental illness and the supernatural. Issues of exorcism and deliverance are discussed in this report as matters of difficult interpretation. Thus while the report's authors are keen to slant the church's beliefs on 'possession' as primarily a psychiatric issue (schizophrenia, drug use, psychological reaction to trauma and abuse) they also leave some room for the theological interpretations of Evangelicals and Pentecostals (Archbishops' Commission: 1958: 173). Possession and possession states are given psychiatric meaning and 'demonic' is described as "powers or influences that are not evil in 
themselves, but which, when diverted from their proper ends, become destructive of human life" (175).

However, we do not wish to reduce or explain away evil oppression or possession simply in medical or psychological terms. We recognise that there are evil forces at work which cannot be psychologically integrated and where the resources of medicine and psychology are only partial solutions. Prayers of deliverance and exorcism, with all the safeguards, may in some cases be appropriate and beneficial (Archbishops' Commission: 178)

This highly nuanced report suggests that although the church is no longer comfortable with the drama of exorcism or deliverance, the avoidance of schism, means that it is unable to shed this aspect of biblical heritage completely.

Globalisation might have once been considered as an answer to the woes of the established churches in the UK with the growing presence of African Christians, a bulwark of resolute spirituality in the face of secularism. However, the distance between African and English brands of Christianity suggests that they may not easily undergo a process of religio-cultural emulsification. As shown here, the clergy appear to resist, fearfully and strongly, African Christian beliefs about witchcraft, the origins of illness and ritual intervention. If such beliefs cannot be accommodated in the mainstream it seems likely that many African Christians will continue to find welcome among the growing African Pentecostal diaspora. The alternative is a greater acceptance of the Evangelical position. On the other hand, it is possible that in relation to supernatural explanations for misfortune, healing and deliverance, the selling points of evangelical Christianity and new age spirituality will become increasingly reincorporated into the mainstream. 
These matters of spirituality and theology may be of considerable relevance to the oft mooted partnership between faith-based organisations and health services. It is argued that religious organisations, as an important cultural resource and behavioural influence should be co-opted into public health programmes (health awareness, suicide prevention) but they also might have utility in understanding (or possibly, managing) the health needs of individual patients (Koenig, 2008). Faith based organisations within the black and minority ethnic communities may help enlighten mental health professionals about various cultural idioms of distress, often religiously framed, or assist mentally ill patients and their families to overcome stigma and to engage with treatment and care (Jarvis, Kirmayer, Weinfeld, \& Lasry, 2005; Leavey, et al., 2007).

\section{Biographical Note}

Gerard Leavey is Professor of Mental Health Services at the Bamford Centre for Mental Health and Wellbeing, Ulster University. He is Co-Lead for the Clinical Research Network-Mental Health in Northern Ireland. He has long-standing research interests in help-seeking and service access of people from disadvantaged communities and backgrounds. He has published widely on ethnicity, migration, religion and clergy.

Kate Loewenthal is Professor Emeritus at Royal Holloway, University of London, where her research and writing focused on the relations between mental health, religion and culture. She has been and/or is associated with a number of other universities, including Visiting Professorships at New York University in London, Heythrop College London, and Glyndwr University. She is associated with several organisations providing mental health support, and continues to teach, write and research in her fields of interest. Publications include Religion, Culture and Mental Health, Cambridge 2007.

Professor Michael King is Professor of Primary Care Psychiatry and joint director of PRIMENT Clinical Trials Unit at University College London. His main interests are randomised trial methodology, primary care mental health, risk prediction in mental health, the stress and stigma faced by gay and lesbian people, the mental health of patients in the late stages of cancer and the role of religious and spiritual beliefs in mental well-being. 


\section{References}

Archbishops Commission. (1958). The Church's ministry of healing: Church Information Board.

Armstrong, K. (2000). The Battle For God. London: HarperCollins.

Bruce, S. (2002). God is dead: secularisation in the west. Oxford: Blackwell.

Calley, M. (1965). God's People: West Indian Pentecostal Sects in England. London: Oxford University Press.

Church Review Group. (2000). A Time to Heal: a contribution towards the ministry of healing. London: Church House Publishing.

Cimpric, A. (2010). Children Accused of Witchcraft: An anthropological study of contemporary practices in Africa. Dakar: UNICEF WCARO, .

Cohen, S. (1973). Folk Devils and Moral Panics. St Albans: Paladin.

Cole, E., Leavey, G., King, M., Sabine, E., \& Hoar, A. (1995). Pathways to care for patients with a first episode of psychosis; a comparison of ethnic groups. British Journal of Psychiatry, 167( 6), 770-776.

Cox, H. (1996). Fire From Heaven. London: Cassell.

Csordas, T. (2002). Body/Meaning/Healing. New York: Palgrave Macmillan.

D'Epinay, C. L. (1969). Haven of the Masses; a study of the Pentecostal movement in Chile. London.: Lutterworth Press.

Davie, G. (1994). Religion in Britain since 1945. London: Blackwell.

Douglas, M. (1996). Natural Symbols (2nd ed.). London: Routledge.

Douglas, M. (2002). Purity and Danger. London: Routledge.

Dura-Vila, G., Hagger, M., Dein, S., \& Leavey, G. (2011). Ethnicity, religion and clinical practice: a qualitative study of beliefs and attitudes of psychiatrists in the United Kingdom. Mental Health, Religion \& Culture, 14, 53-63.

Durkheim, E. (2001). The elementary forms of religious life. Oxford: Oxford University Press.

Eliacin, J. (2013). Social capital, narratives of fragmentation, and schizophrenia: an ethnographic exploration of factors shaping African-Caribbeans' social capital and mental health in a North London community. Culture Medicine and Psychiatry, 37(3), 465-487. 
Finke, R., \& Stark, R. (1992). The Churching of America: Winners and Losers in Our Religious Economy, 1776-1990. New Brunswick, New Jersey: Rutgers University Press.

Friedli, L. (1999). Promoting Mental Health:the role of faith communities - Jewish and Christian communities. London: Health Education Authority.

Gerloff, R. (1992). A Plea for British Black Theologies. Frankfurt: Peter Lang.

Gerrish, K., Husband, C., \& Mackenzie, J. (1996). Nursing for a multi-ethnic society. Buckingham: Open University Press.

Glik, D. C. (1988). Symbolic, ritual and social dynamics of spiritual healing. Social Science and Medicine, 27(11), 1197-1206.

Green, V. (1996). A new history of Christianity. Stroud, England: Sutton Publishing.

Hornsby-Smith, M. P. (1999). English Catholics at the New Millennium. In M. P. Hornsby-Smith (Ed.), Catholics in England 1950-2000; historical and sociological perspectives (pp. 291-306). London: Cassell.

Hunt, S. (2001). The British black Pentecostal 'revival':identity and belief in the 'new' Nigerian churches. Ethnic and Racial Studies, 24(1), 104-124.

Jackson, M. C. (1991). A study of the relationship between psychotic and spiritual experience. Oxford.

James, W. (1902). The Varieties of Human Experience: A Study in Human Nature. New York.

Jarvis, G. E., Kirmayer, L. J., Weinfeld, M., \& Lasry, J.-C. (2005). Religious Practice and Psychological Distress: The Importance of Gender, Ethnicity and Immigrant Status Transcultural Psychiatry, 42 (4), 657-675.

Jasper, A. (2003). Christianity. In L. Ridgeon (Ed.), Major World Religions: from their origins to their present (pp. 178-229). London: Routledge.

Kleinman, A. (1981). Patients and healers in the context of culture; an exploration of the borderland between, Anthropology, Medicine and Psychiatry. Los Angeles: University of California Press.

Kleinman, A., Eisenberg, L., \& Good, B. (1978). Culture, Illness and care: Clinical lessons from anthropologic and cross-cultural research. Annals of Internal Medicine(88), 251-258.

Koenig, H. G. (2008). Religion and mental health: what should psychiatrists do? Psychiatric Bulletin, 32, 201-203

Laming. (2003). The Victoria Climbie Inquiry. London: Crown Publications. 
Leavey, G. (2004). Identity and belief within black Pentecostalism. In D. Kelleher \& G. Leavey (Eds.), Identity and Health (pp. 37-58). London: Routledge.

Leavey, G. (2008). UK Clergy and People in mental distress: community and patterns of pastoral care. Transcultural Psychiatry, 45, 79-104.

Leavey, G. (2010). The appreciation of the spiritual in mental illness: A qualitative study of beliefs among clergy in the UK. Transcultural Psychiatry, 47(4), 571590.

Leavey, G., \& King, M. (2007). The devil is in the detail: partnerships between psychiatry and faith-based organisations. British Journal of Psychiatry, 191, 97 - 98.

Leavey, G., Loewenthal, K., \& King, M. (2007). Challenges to Sanctuary: the clergy as a resource for mental health care in the community Social Science and Medicine, 65, 548-559.

Leavey, G., Rondon, J., \& McBride, P. (2011). Between compassion and condemnation: a qualitative study of clergy views on suicide in Northern Ireland. Mental Health, Religion \& Culture, 14(1), 65-74.

Martin, D. (2002). Pentecostalism: The world their parish. Oxford: Blackwell.

Maton, K. (1989). The stress buffering role of spiritual support: cross-sectional and prospective investigations. Journal for the Scientific Study of Religion, 28, 310-323.

Parekh, B. (2000). The Future of Multi-ethnic Britain; the Parekh Report. London: The Runymede Trust.

Pargament, K. I. (1997). The Psychology of Religion and Coping; Theory, research, practice (1st ed.). New York: Guilford.

Pennacini, C. (2013). Mediating African Religions: the case of Pentecostalism Lexia, $11-12,247-261$.

Sashidharan, S. P. (2001). Institutional racism in British Psychiatry. Psychiatric Bulletin, 25, 244-247.

Singh, S. P. (2007). Institutional racism in Psychiatry:lessons from inquiries. Psychiatric Bulletin, 31, 363-365.

Smart, N. (2005). World Philosophies. London: Routledge.

Strauss, A., \& Corbin, J. (1990). Basics of qualitative research: Grounded theory procedures and techniques. London: Sage. 
Sue, D. W., Arredondo, P., \& McDavis, J. (1992). Multicultural counselling competencies and standards: A call to the profession. Journal of Counselling \& Development, 70, 477-486.

Swift, R. (2002). Irish migrants in Britain, 1815-1914: a documentary history

Cork: Cork University Press

Terry, K. E. (2008). Stained Glass: The Nature and Scope of Child Sexual Abuse in the Catholic Church. Criminal Justice and Behavior 35, 359-569.

Toulis, N. R. (1997). Believing Identity; Pentecostalism and the Mediation of Jamaican Ethnicity and Gender in England. Oxford.: Berg.

Weber, M. (1947). The Theory of Social and Economic Organization. Translated by A. M. Henderson \& Talcott Parsons. New York: The Free Press.

Zuckerman, D., Kasl, S., \& Osfield, A. (1984). Psychological predictors of mortality among the elderly poor: The role of religion, well-being and social contacts. American Journal of Epidemiology, 119, 410-423.

\section{Acknowledgements:}

We are deeply indepted to the clergy who generously contributed their time and knowledge to this study. Many thanks also to Veronica (Cecilia) Burns who assisted in transcribing the many hours of interviews.

\footnotetext{
${ }^{\text {i }}$ Finke and Stark (1992) draw on an examination of the fluctuating fortunes of Methodists, Baptists and Congregationalists in the USA to show how churches decline as they 'pitch their wares' to a more liberal elite and move away from the other-worldly and conservative instincts of the broader base. They argue that religious monopolies, which need not compete for souls in the marketplace, are inclined to loose members as the organisation become impervious to the spiritual needs of the people.

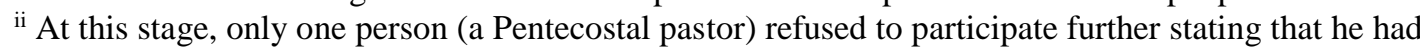
not previously understood the aims of the study and "did not like being scrutinised by psychologists". iii For example, in Haringey, North London, where the study was primarily based, there are more than one hundred community languages spoken. The Census 2011 shows $45 \%$ of Haringey residents were Christian, slightly less than the $48.4 \%$ in London overall. The second most common religion stated was Muslim followed by Hindu and Jewish. The profile of Haringey is well-documented in Eliacin's excellent ethnographic study of African-Caribbeans and mental illness (Eliacin, 2013).

iv The Evangelical Alliance (EA) is an association of Protestants belonging to various denominations and founded in 1846. It has a strong appeal to many of the conservative groupings within the Church of England and also to African and Pentecostals who put conversion and belief in the power of the Holy Spirit. The commonality with Pentecostals can be seen within EA literature and material placed on the official EA internet website. For example, the EA appear to be pushing towards a 'cell model' of church membership or "scattered church" approach that emphasises meetings in small groups gatherings away from the church as building. The EA within the Church of England has been presented a powerful block against the ordination of women and currently, homosexuals.

${ }^{v}$ Including departure from the hierarchical churches whereby faith members may identify with the 'faith community' but also see no contradiction in demanding the right to personal freedom on matters of belief and worship (see for example, the observed shift from official Catholicism to 'customary Catholicism' discussed in Hornsby-Smith, 1999)
} 